\title{
Effects of Adding Cysteine or Ascorbic Acid on the Quality of Frozen Semen from Arabian Stallions
}

\author{
Alamaary Mohaammed Saad ${ }^{1,3}$, Abd Wahid Haron ${ }^{1 *}$, Mohamed Ali², \\ Mark Wen Han Hiew ${ }^{1}$ and Lawan Adamu ${ }^{1}$ \\ ${ }^{1}$ Department of Veterinary Clinical Studies, Faculty of Veterinary Medicine, Universiti \\ Putra Malaysia, UPM, 43400 Serdang, Selangor Darul Ehsan, Malaysia \\ ${ }^{2}$ Animal Production and Breeding, Faculty of Agriculture and Veterinary Medicine, \\ Qassim University, Qassim State, Saudi Arabia \\ ${ }^{3}$ King Abdulaziz Arabian Horses Center, Ministry of Agriculture, Riyadh, Saudi Arabia
}

\section{A B S T R A C T}

Spermatozoa are susceptible to the oxidative stress OS during cryopreservation. The excessive reactive oxygen species (ROS) and the capacity of the antioxidants could affect the OS level in the frozen semen. This study was to determine the addition of different concentrations of antioxidants to evaluate oxidative stress and fertility of frozen semen in horses. Seven stallion were used for semen collection in this study. A total of twenty ejaculates was collected from three healthy stallions twice a week for the experiments 1 and 2. All ejaculates were divided into two parts of ten ejaculates each, ten ejaculates for cysteine in experiment 1 and the other ten for ascorbic acid groups in experiment 2. Each ejaculate from an individual horse was divided into six equal parts of the study, and they were cryopreserved using the same procedure. Different concentrations of either cysteine $(0,0.25,0.5,1,2$, and $4 \mathrm{mg} / \mathrm{ml})$ or ascorbic acid $(0,0.25,0.5$, 1,2 , and $4 \mathrm{mg} / \mathrm{ml}$ ) were added to the semen of the first and second experiments. HF-20 containing no ascorbic acid and cysteine was used as a control. The post-thawed semen from all the samples were assessed for motility, oxidative stress, sperm membrane integrity, morphology, and acrosome integrity. Four stallions were nominated for AI in the current study. The best result from different concentrations of cysteine and ascorbic acid were used for AI. Thirty mares were divided into three groups of 10 mares each and were then inseminated using the frozen semen with the following extenders: HF-20 extender $(0)$ as control, 0.5 cysteine, and 0.5 ascorbic acid. The level of oxidative stress steadily increases with increase concentrations of cysteine and ascorbic acid. Although the samples treated with cysteine and those with low concentrations of ascorbic acid showed lower level of oxidative stress, the control group revealed a much better protection of oxidative stress. The supplementation of cysteine and ascorbic acid showed an adverse effect on sperm motility, membrane integrity, and viability. Nonetheless, those with cysteine and ascorbic acid recorded better sperm morphology and acrosome integrity than those from the control group. Furthermore, the fertility of frozen semen was better with the cysteine groups than with the ascorbic acid groups. The addition of antioxidant needs further adjustment on frozen stallion semen due to changes in $\mathrm{pH}$, osmolality and cryoprotectants capacity.
\end{abstract}

\begin{tabular}{l} 
Article Information \\
\hline Received 26 November 2019 \\
Revised 01 March 2020 \\
Accepted 30 April 2020 \\
Available online 04 June 2021 \\
Authors' Contribution \\
\hline MSA, AWH, MA, MWHH conceived \\
the idea and designed the main frame \\
of this manuscript. MSA performed \\
experimental work. AWH supervised \\
the work. MSA processed and \\
evaluated the post-thawed semen. LA \\
helped in preparation of the article. \\
Key words \\
\hline $\begin{array}{l}\text { Arabian stallions, Ascorbic acid, } \\
\text { Antioxidant, Cysteine, Frozen semen }\end{array}$
\end{tabular}

\section{INTRODUCTION}

$\mathrm{C}$ urrently, artificial insemination (AI) in horses is generally less successful than in other species due to less interest in research on horses after World War I (Aurich, 2012). Although cryopreservation of stallion semen is the main technology used to develop the horse industry (Loomis and Graham, 2008), it is assumed that individual variations and less resistance of horse spermatozoa to cryopreservation caused the minimal use of this technology.

\footnotetext{
* Corresponding author: wahidh@upm.edu.my; wahidharon@gmail.com 0030-9923/2021/0004-1467 \$ 9.00/0

Copyright 2021 Zoological Society of Pakistan
}

Recently, the oxidative stress in the seminal plasma was revealed to be responsible for $30 \%$ to $40 \%$ of male infertility (Agarwal et al., 2014). Furthermore, oxidative stress is one of the main causes of lower frozen semen quality. Sperm live under aerobic conditions; hence, they need oxygen $\left(\mathrm{O}_{2}\right)$ for sperm metabolism. Therefore, reactive oxygen species (ROS) must be balanced during sperm metabolism to prevent the modification of sperm function that can lead to sperm damage during cryopreservation (Agarwal, 2003; Donnelly et al., 1999). Low concentrations of ROS mediators, both free radical and non-radical, is important for normal sperm function. Disruption of spermatozoa may occur when these mediators are increased beyond the permissible limit. Sperm damage can be mediated by lipid peroxidation or reduction of ATP or by decreasing the sperm 
enzymes that diminish sperm defenses against oxidative damage (Agarwal et al., 2006). The sperm function and structure could be damaged by the ROS reaction with the spermatozoa's enzymes, membrane phospholipid and chromatin (Aitken, 2017). This causes lipid peroxidation, protein oxidation and DNA fragmentation (Bui et al., 2018; Morielli and O'Flaherty, 2015). Furthermore, excessive ROS might impair the mitochondrial and enzyme reactions (Treulen et al., 2018).

The spermatozoa are unable to repair the damage caused by OS unlike other cell types due to the absence of cytoplasmic-enzyme repair systems. Furthermore, spermatozoa membranes contain high concentrations of polyunsaturated fatty acids, which make the spermatozoa more susceptible to oxidative stress than other cell types. The disruption that caused by oxidative stress encountered by the antioxidants, which exist naturally in the spermatozoa and seminal plasma as enzymatic and non-enzymatic antioxidants. The cytoplasm of body cells have high concentrations of enzymatic antioxidants, but in the spermatozoa these enzymes are removed from the cytoplasm at the end of the spermatogenesis phase. Therefore, the antioxidant defense mechanisms in semen samples depend only on the antioxidants in the seminal plasma (Smits et al., 2018). Oxidative stress is a crucial factor during semen cryopreservation, especially when the removal of the seminal plasma is part of the freezing process (Ball, 2008). Therefore, ROS can be balanced by adding suitable antioxidants into the semen extender. The addition of enzymatic or non-enzymatic antioxidants to the frozen semen extender has been proven to decrease the oxidative stresses on the stallion semen during semen cryopreservation and enhance the frozen semen performance (Agarwal et al., 2004).

Furthermore, ascorbate has been proven to be a coantioxidant (Du et al., 2012). Ascorbic acid is a safe antioxidant and acts as a "chain breaker" by removing free radicals that stop the peroxidation process (Zhang et al., 2012). Cysteines are amino acids that have the ability to penetrate cell membranes and inside the cell they are metabolize to taurine, which combine with a fatty acid in the sperm membrane to protect the cell walls (De Pinto et al., 2016). The purpose of the present study is to evaluate the effect of the addition of different concentrations of cysteine and ascorbic acid to HF20 extender and to assess the quality of frozen semen in horses based on sperm motility, oxidative stress, membrane integrity, viability, acrosome integrity, and morphology. Furthermore, the AI was used to evaluate the fertility rate for frozen semen that supplemented with cysteine or ascorbic acid.

\section{MATERIALS AND METHODS}

Exemptions were granted to this study from being approved by the Institution of Animal Ethics due to the fact that the animals' normal physiology is not affected by semen collection through the use of artificial vagina.

\section{Animals}

In this study, 30 healthy mares aged between 3-12 years and 7 stallions aged between 4-10 years were chosen following a breeding soundness analysis. Three out of the 7 stallions were kept within the Research Unit at AlQassim University's farm for experiment 1 and experiment 2 (which investigated the effect of different concentration of cysteine and ascorbic acid). Four stallions and 30 mares were housed individually in the King Abdulaziz Arabian Horses Center in Dirab (KAAH), which is a member of World Arabian Horse Organization (WAHO) for artificial insemination purpose. All the animals offered pellets, alfalfa hay, clean water, and integrated mineral licks. Reserves of epididymal sperms were reduced through daily collection of semen from every stallion for about 3 days. Rhythm semen collections were performed using an automated semen collection, phantom twice a week per stallion. Twenty ejaculates were collected from three stallions for experiments 1 and 2 .

\section{Semen collection and processing}

An automated semen collection, phantom (Equidame phantom, Haico, Loimaa, Finland) was used for semen collection in this trial. The AV temperature was set at $45^{\circ} \mathrm{C}$, whereas non-spermicidal lubricant (Minitube, Germany) was applied in the AV. All the semen collection equipment was subjected to $37^{\circ} \mathrm{C}$ warming. The Equidame phantom height for all stallions was controlled. A mare on estrus was utilised for teasing stallions during the collection of semen. The gel was immediately removed from the semen after their collection. Sterile gauze was used to filter the collected sample then moved into a water bath at a temperature of $37^{\circ} \mathrm{C}$. The amount of the semen was measured using a calibrated cylinder then analyzed for sperm concentration and overall progressive motility. The Computer-assisted sperm analysis (CASA) system (Prosser R+D, ISAS program Paterna, Valencia, Spain) was used to determine sperm concentration and motility. Samples whose motility was more than $60 \%$ and at least $200 \times 10^{6} \mathrm{sperm} / \mathrm{ml}$ concentration were used for this research.

A centrifugation media was used to dilute the semen that was filtered in every ejaculate as a ratio of 1:1 and divided into 6 aliquots which were centrifuged for about 10 minutes at $800 \mathrm{~g}$. Thereafter, removal of seminal plasma 
was performed and every sample suspended again with FH-20 (0) in absence of any supplementation to act as a control, and $0.25 \mathrm{mg} / \mathrm{ml}, 0.5 \mathrm{mg} / \mathrm{ml}, 1 \mathrm{mg} / \mathrm{ml}, 2 \mathrm{mg} / \mathrm{ml}$ and $4 \mathrm{mg} / \mathrm{ml}$ of cysteine in the first experiment or ascorbic acid in the second experiment. The resulting concentration of semen was adjusted to be $200 \times 10^{6} \mathrm{sperm} / \mathrm{ml}$ after dilution. Tubes were then cooled for about 90 minutes to $4^{\circ} \mathrm{C}$ in the cooling chamber. The cooled samples were assessed before freezing for the motility, sperm membrane integrity and morphology. The semen that was cooled was placed in $0.5 \mathrm{ml}$ straws via semiautomatic filling and a sealing system (Minitube, Germany). Then a programmable freezer (IceCube machine $14 \mathrm{~S}-\mathrm{A}$, Minitube, Germany) was used to freeze the straws at $60^{\circ} \mathrm{C} / \mathrm{min}$ to $-140^{\circ} \mathrm{C}$. They are then dropped stored in liquid nitrogen at a temperature of $-196^{\circ} \mathrm{C}$.

\section{Extenders}

The centrifugation media was a mixture of $0.08 \mathrm{~g}$ streptomycin, $6.0 \mathrm{~g}$ glucose, $0.12 \mathrm{~g}$ sodium bicarbonate, $0.37 \mathrm{~g}$ ethylene-diamine-tetra-acetic acid (EDTA), 100,000 IU penicillin and $0.37 \mathrm{~g}$ sodium citrate in $100 \mathrm{ml}$ distilled water.

In preparing a freezing extender (HF-20) (Nishikawa, 1975), $5.0 \mathrm{~g}$ glucose, $0.15 \mathrm{~g}$ sodium citrate, $0.05 \mathrm{~g}$ sodium potassium tartrate, $0.3 \mathrm{~g}$ lactose, $3 \mathrm{ml}$ glycerol, $00.05 \mathrm{~g}$ sodium phosphate and $0.3 \mathrm{~g}$ raffinose were dissolved in distilled water $(50 \mathrm{ml})$. About $10 \mathrm{ml}$ of egg yolk (EY) was then added to act as a basic buffer after which addition of distilled water was done to act as a control extender $(100 \mathrm{~mL})$ at a $\mathrm{pH}$ of 7.4. Cysteine at different concentrations (that is, $0.25,0.50,1.0,2.0$, or $4.0 \mathrm{mg} / \mathrm{mL}$ ) was dissolved in the basic buffer. For the ascorbic acid, the same concentrations were used as in the cysteine. The $\mathrm{pH}$ of the extender was adjusted using sodium bicarbonate buffer to 7.4. Measurements of $\mathrm{pH}$ were adjusted using a pH meter (Hanna, model HI-2212, Woonsocket, RI, USA). The osmolarity of extenders including cysteine or ascorbic acid were 300 to 350 . The measurement of the extender osmolarity (mOsmol/ $\mathrm{kgH} 2 \mathrm{O}$ ) was determined by osmometer (model 800 CLG, SLAMED, Germany).

\section{Frozen semen evaluation}

The frozen straws were thawed in a water bath at $37^{\circ} \mathrm{C}$ for 30 seconds, and the contents were expelled into a small warm tube. The general and progressive motility was then evaluated using the ISAS program (Proiser R $+\mathrm{D}$, Spain) and assessed for oxidative stress, plasma membrane integrity, morphology defects, acrosome integrity, and viability. The frozen semen evaluation was conducted at the AI Center for Animal Production and Breeding, Al Qassim University.

\section{Assessment of sperm motility}

Motility patterns were evaluated just after semen or post-thawed semen dilution using the CASA system (ISAS program). Disposable counting chambers slides (ISASD4C10, Prosser R+D, Paterna, Valencia, Spain) were used. A sample of about 2.7 microliters was drawn from every tube then placed on a slide after which semen motility was analyzed with regard to 5 digital images from various fields through a $\times 10$ negative-phase contrast warm stage and objective at a temperature of $37^{\circ} \mathrm{C}$. The measurement of motility patterns was done based on the rapid progressively motile (RPS \%), total motile sperm (TMS \%), rectilinear speed (VSL $\mu \mathrm{m} / \mathrm{s}$ ), linearity index (LIN \%), curvilinear speed (VCL $\mu \mathrm{m} / \mathrm{s}$ ), straightness index (STR \%) and average value (VAP $\mu \mathrm{m} / \mathrm{s})$. Straightness index is calculated as follows: $\mathrm{STR}=\mathrm{VSL} / \mathrm{VAP} \times 100)$ while the linearity index is calculated as: $\mathrm{LIN}=\mathrm{VSL} / \mathrm{VCL} \times 100$. Sperm motility parameters that were featured involved RMS \% (rapid motile sperm), MMS \% (medium motile sperm) and SMS \% (slow motile sperm). Sperm progressive motility duplicates the swimming speed of 10-45, 45-90, and over $90 \mu \mathrm{m} / \mathrm{s}$. A sperm whose VAP value was $\leq 10 \mu \mathrm{m} / \mathrm{s}$ and swimming velocity was less than $10 \mu \mathrm{m} / \mathrm{s}$ was said to be an immotile sperm. Spermatozoa percentage with over $10 \mathrm{ml} / \mathrm{s}$ VAP was said to have total sperm motility while that with more than $75 \%$ STR was said to be a progressive motility. Over 300 sperms were evaluated from every sample and images read in a single second.

\section{Evaluation of oxidative stress levels}

The oxidative stress levels in the semen sample were evaluated using an Oxisperm kit (Halotech DNA S.L., Madrid, Spain). The test was performed by following the instructions that came with the kit. First, all of the semen samples were diluted to a concentration of $1 \times 10^{6} \mathrm{sperm} /$ $\mathrm{ml}$. Then the reactive gel (RG) was liquefied using a water bath at $90^{\circ} \mathrm{C}$ for 5 minutes. After the temperature of the RG dropped to $37^{\circ} \mathrm{C}$, the semen samples and reactive gel were mixed $(1: 1)$ at $37^{\circ} \mathrm{C}$. The mixture was then cooled at $4^{\circ} \mathrm{C}$ for 5 minutes to be gelified and incubated at $37^{\circ} \mathrm{C}$ for 45 minutes. Finally, the oxidative stress appeared as different levels of colors that corresponded to a color scheme. Colors grades from yellow to the purple-blue in the $R G$ can be visualized and compared by the eye. Levels N1 and N2 were considered low levels of oxidative stress (LOS) that cannot damage the sperm. Levels N3 and N4 were considered high levels of oxidative stress (HOS) that may have a pathological effect on sperm (Sobhani et al., 2015).

Manufacturer's instructions indicated that, higher sperm concentration will increase the OS in the samples and the colors as well. Thus, parallel experiments were conducted as positive controls in the present study. In this 
experiment, the test was performed as explained previously (following the manufacturer's instructions) with higher sperm concentration $\left(200 \times 10^{6} \mathrm{sperm} / \mathrm{ml}\right.$ instead of $1 \times$ $10^{6} \mathrm{sperm} / \mathrm{ml}$ ). Escalating the oxidative stress within all treated groups elucidated the oxidative stress differences among the groups alongside their capacity of encountering the oxidative stress. To our knowledge, this is the first report that describes the possibility to use Oxisperm kit for semen evaluation of stallion.

\section{Plasma membrane integrity}

The spermatozoa's plasma membrane integrity was assessed using a HOST (hypo-osmotic swelling test). Phase contrast microscopy $(\times 400)$ was used to examine over 100 sperm cells for the coiled tail. A sucrose-based solution was mixed at $100 \mathrm{mOsmol}$ after which incubation of $20 \mu \mathrm{l}$ of semen was done for about 50 minutes at a temperature of $37^{\circ} \mathrm{C}$ within a water bath (Neild et al., 1999).

\section{Viability test}

A propidium iodide $(\mathrm{PI})$ and acridine orange $(\mathrm{AO}) \mathrm{kit}$ (Halotech, VitalTest ${ }^{\circledR}$, Madrid, Spain) was used to assess sperm viability. Semen was first diluted to $10-15 \times 10^{6}$ sperm $/ \mathrm{ml}$ after which the diluted semen $(10 \mu \mathrm{l})$ was placed onto a slide. The diluted semen was mixed with $1 \mu$ l of PI and $\mathrm{AO}$ then covered and assessed through the use of a fluorescence microscope (Optika, Italy B-353 LD2). The $\mathrm{AO}$ was retained by the living sperm thus producing green fluorescence. On the other hand, the damaged sperm was penetrated by PI thus causing red fluorescence. There were 300 sperms that were evaluated in every sample.

\section{Morphology}

Eosin-nigrosin staining technique (RAL Diagnostics, Martillac, France) was used to examine sperm morphology. A $15 \mu \mathrm{l}$ eosin-nigrosin was mixed with an equal amount of semen on a warm and clean slide then smeared. In addition, the mixture was spread gently and randomly assessed at $1000 \times$ magnification under oil immersion. Morphological defects of the spermatozoa were categorized as abnormal head, normal, abnormal tail, abnormal acrosome, proximal droplet, abnormal midpiece, bent tail, head detached and distal droplet (Murcia-Robayo et al., 2018).

\section{Acrosome integrity}

A drop of semen sample was mixed with a drop of isotonic $0.2 \%$ trypan blue $(0.4 \%$ trypan blue and $0.9 \%$ sodium chloride $\mathrm{NaCl}$ ) on a clean and warmed microscope slide. The mixture was then smeared and dried and placed for five minutes in a fixative solution of $0.2 \mathrm{~g}$ neutral red, $86 \mathrm{ml}$ hydrogen chloride $\mathrm{HCl}$, and $14 \mathrm{ml}$ formaldehyde. The slide was then stained with Giemsa for more than $3 \mathrm{~h}$ at $25^{\circ} \mathrm{C}$. Finally, the slide was washed using distilled water and dried. A light microscope at $\times 1000$ was used to assess at least 200 sperm for acrosome defects.

\section{Artificial insemination of mares}

Thirty foaling mares (aged 3 to 12 years) were used for artificial insemination (AI). All mares were clinically normal without any record of reproductive failures or the disturbances. The external and internal genitalia were examined using the rectal palpation and ultrasonography to avoid any disturbance in the reproductive tract that might affect mare's fertility.

The mares were equally divided into three groups and inseminated using different extenders. The extenders used were control extender, $0.5 \mathrm{mg} / \mathrm{ml}$ cysteine, and $0.5 \mathrm{mg} / \mathrm{ml}$ ascorbic acid.

Mares within the estrus containing a typical uterine edema (cartwheel pattern) and follicle $\geq 35 \mathrm{~mm}$ were subjected to insemination. Grading of estrus edema was done on a 1 to 5 scale with regards to description (Samper, 2009) in this study. However, estrus edema whose grading ranged from 2 to 4 was said to be ideal for insemination. $3000 \mathrm{IU}$ of hCG (human chorionic gonadotrophin) were intravenously injected into all mares to stimulate ovulation. After that, the dominant follicles were monitored after 18 $\mathrm{h}$ of injection at an interval of $6 \mathrm{~h}$ until the ovulation time. The timing of ovulation was ultrasonographically (ExaGo portable ultrasound scanner, IMV imaging, France) proven through the use of a transrectal probe (LR760P Linear rectal probe at $7.5 \mathrm{MHz}$ ). All the ovaries were scanned and follicle sizes registered. The disappearance of the dominant follicle triggered the insemination of mares. A flexible $75 \mathrm{~cm}$ pipette was used to deposit insemination doses into the uterine horn. There were $4 \mathrm{ml}$ doses of $800 \times 10^{6}$ total sperm i.e. 8 straws with every straw comprising of $100 \times 10^{6}$. After ovulation, every dose was deposited in at least six $\mathrm{h}$ and pregnancy test conducted after 30 days of ovulation.

\section{Statistical analysis}

One-way ANOVA with Dunnett's control as a post hoc test for comparison was used to analyze the data. The homogeneity of variances in the samples was confirmed using Levene's test. The chi-squared test and Mosaic presentation were used to describe the association between the control, cysteine, and ascorbic acid groups in term of pregnancy rate. Using SPSS statistical software version 16.0 , the result obtained was significant at $\mathrm{p}<0.05$.

\section{RESULTS}

Assessing sperm motility before freezing and after cooling for 90 minutes for cysteine groups is presented in 
Table I. In general, no variations were observed between all groups treated with cysteine in general and progressive motility. Furthermore, there were no variations observed between all groups treated with cysteine and control in terms of VCL, VAP and LIN. The high cysteine concentrations 1,2 and $4 \mathrm{mg} / \mathrm{ml}$ revealed significant reduction in spermatozoa VSL and STR's motility patterns after 90-minutes of cooling. The variations in sperm membrane integrity and sperm morphology were not significant as presented in Table II.

Evaluation of the semen supplemented with ascorbic acid and chilled for 90 minutes before freezing for studying the motility pattern (general and progressive motility, VCL, VSL, VAP, LIN and STR) as shown in Table I. There was a decrease $(p<0.05)$ in all sperm motility patterns in the group treated with $4 \mathrm{mg} / \mathrm{ml}$ ascorbic acid. There were no variations between the other groups and control samples in terms of motility pattern. Table II shows no effect of adding ascorbic acid in sperm membrane integrity and morphology before freezing.

\section{Sperm motility}

There was a decrease $(p<0.05)$ in the post-thaw semen quality parameters for all of the groups that were supplemented with cysteine and ascorbic acid compared to the control group with no supplementation. In Table III the total motility was higher $(\mathrm{p}<0.05)$ in the control group than the other treatment groups except the group treated with $0.5 \mathrm{mg} / \mathrm{ml}$ cysteine and ascorbic acid. Progressive motility in all of the treated groups was lower than the control group ( $p<0.05)$. The rectilinear speed (VSL), average value (VAP) and curvilinear speed (VCL) were lower i.e. $\mathrm{p}<0.05$ within the groups that were treated using cysteine $4 \mathrm{mg} / \mathrm{ml}$ compared to the control group. On the other hand, all groups that were treated using ascorbic acid had lower sperm velocity $(\mathrm{p}<0.05)(\mathrm{VSL}$, VAP and VCL) compared to the control group.

Sperm membrane integrity, viability, morphology, and acrosome integrity

Table IV shows the effect of adding different concentrations of cysteine and ascorbic acid on cryopreserved sperm membrane integrity, viability, morphology, and acrosome integrity. The sperm membrane integrity was lower $(\mathrm{p}<0.05)$ in the groups treated with cysteine and ascorbic acid compared to the control group. The sperm viability did not show any differences compared to the control except in the groups supplemented with $0.25 \mathrm{mg} / \mathrm{ml}$ cysteine and $4 \mathrm{mg} / \mathrm{ml}$ ascorbic acid, which were lower $(\mathrm{p}<0.05)$ than the control. Even though the normal sperm morphology revealed better results in 0.5 $\mathrm{mg} / \mathrm{ml}$ cysteine, $1 \mathrm{mg} / \mathrm{ml}$ cysteine, 1 and $2 \mathrm{mg} / \mathrm{ml}$ ascorbic acid, these variations were not significant. The acrosome integrity had better characteristics $(p<0.05)$ in all of the groups supplemented with cysteine or ascorbic acid compared to the control group except in the group that was treated with $4 \mathrm{mg} / \mathrm{ml}$ cysteine and ascorbic acid, which had lower acrosome integrity.

\section{Oxidative stress}

The levels of oxidative stress that accrued from the post-thawed semen treated with cysteine was measured using the commercial Oxisperm kit. All of the groups treated with cysteine and control had low levels of oxidative stress (LOS). In the positive control samples with high sperm concentrations, the oxidative stress increased in the cysteine groups. The groups containing $0.25 \mathrm{mg} / \mathrm{ml}$ and $0.5 \mathrm{mg} / \mathrm{ml}$ cysteine had low levels of oxidative stress. The groups supplemented with $1 \mathrm{mg} / \mathrm{ml}, 2 \mathrm{mg} / \mathrm{ml}$ and $4 \mathrm{mg} / \mathrm{ml}$ cysteine had high levels of oxidative stress. Whereas the control group did not react.

The level of oxidative stress in the semen treated with ascorbic acid was measured using the commercial Oxisperm kit. The groups treated with $0.25,0.5$, and $1 \mathrm{mg} /$ $\mathrm{ml}$ of ascorbic acid had low oxidative stress (LOS). The LOS samples with optimal/low levels of ROS were thought to be unable to damage cells. The high levels of oxidative stress (HOS) observed in the groups supplemented with 2 and $4 \mathrm{mg} / \mathrm{ml}$ of ascorbic acid may have caused pathological effects on the sperm. The oxidative stress, increased progressively with the increase in ascorbic acid concentration until the maximum concentration of $4 \mathrm{mg} /$ $\mathrm{ml}$. The control group had the lowest oxidative stress compared to the groups supplemented with ascorbic acid.

The level of oxidative stress in the positive control samples with high sperm concentrations. The reaction with ascorbic acid concentration of $0.25 \mathrm{mg} / \mathrm{ml}$ was in level N3, while the concentrations of $0.5 \mathrm{mg} / \mathrm{ml}, 1 \mathrm{mg} / \mathrm{ml}, 2 \mathrm{mg} / \mathrm{ml}$, and $4 \mathrm{mg} / \mathrm{ml}$ were at $\mathrm{N} 4$. Thus, all were considered to have high levels of oxidative stress (HOS). No reactions were observed in the control group.

\section{Artificial insemination}

The number of conceived mares per cycle were recorded for the 30 mares' inseminated using frozen semen supplemented with either $0.5 \mathrm{mg} / \mathrm{ml}$ cysteine or $0.5 \mathrm{mg} / \mathrm{ml}$ ascorbic acid or control at 15 days after ovulation. Five pregnant mares detected from the 10 mares were inseminated with cysteine extender. There was one pregnant mare out of the 10 mares that were inseminated with ascorbic acid extender. Using the control extender, four pregnant mares were diagnosed as pregnant out of the 10 mares inseminated. The pregnancy rate with the 
Table I. Effect of adding different concentrations of cysteine and ascorbic acid in HF-20 extender on chilled stallion semen after 90 minutes sperm motility parameters in horses. Ten ejaculates were selected from 3 stallions.

\begin{tabular}{|c|c|c|c|c|c|c|c|}
\hline \multirow[t]{2}{*}{ Treatment } & \multicolumn{7}{|c|}{ Parameters } \\
\hline & Motility (\%) & PM (\%) & $\operatorname{VCL}(\mu \mathrm{m} / \mathrm{s})$ & VSL $(\mu \mathrm{m} / \mathbf{s})$ & $\operatorname{VAP}(\mu \mathrm{m} / \mathrm{s})$ & LIN (\%) & STR (\%) \\
\hline Control (0) & $67.32 \pm 9.47^{\mathrm{a}}$ & $34.05 \pm 2.36^{\mathrm{a}}$ & $93.66 \pm 1.01^{\mathrm{a}}$ & $29.78 \pm 2.72^{\mathrm{a}}$ & $51.70 \pm 2.69^{\mathrm{a}}$ & $30.07 \pm 0.84^{\mathrm{a}}$ & $57.42 \pm 1.81^{\mathrm{a}}$ \\
\hline \multicolumn{8}{|c|}{ Cysteine (mg/ml) } \\
\hline 0.25 & $67.08 \pm 7.11^{\mathrm{a}}$ & $39.56 \pm 6.27^{\mathrm{a}}$ & $89.17 \pm 10.88^{\mathrm{a}}$ & $24.44 \pm 2.37^{\mathrm{ab}}$ & $46.72 \pm 5.26^{\mathrm{ab}}$ & $27.70 \pm 0.91^{\mathrm{a}}$ & $52.52 \pm 0.94^{\mathrm{b}}$ \\
\hline 0.5 & $62.92 \pm 5.94^{\mathrm{a}}$ & $35.57 \pm 5.36^{\mathrm{a}}$ & $84.46 \pm 5.45^{\mathrm{a}}$ & $24.15 \pm 1.53^{\mathrm{b}}$ & $44.52 \pm 2.97^{\mathrm{ab}}$ & $28.70 \pm 1.17^{\mathrm{a}}$ & $54.21 \pm 1.73^{\mathrm{ab}}$ \\
\hline 1 & $58.18 \pm 7.20^{\mathrm{a}}$ & $28.40 \pm 4.32^{\mathrm{a}}$ & $78.15 \pm 6.47^{\mathrm{a}}$ & $21.32 \pm 1.27^{\mathrm{b}}$ & $40.92 \pm 2.47^{b}$ & $27.99 \pm 0.97^{\mathrm{a}}$ & $52.27 \pm 1.00^{\mathrm{b}}$ \\
\hline 2 & $65.04 \pm 5.95^{\mathrm{a}}$ & $36.18 \pm 4.62^{\mathrm{a}}$ & $77.33 \pm 5.11^{\mathrm{a}}$ & $21.66 \pm 1.19^{\mathrm{b}}$ & $41.09 \pm 2.05^{\mathrm{ab}}$ & $28.42 \pm 0.88^{\mathrm{a}}$ & $52.63 \pm 0.50^{\mathrm{b}}$ \\
\hline \multicolumn{8}{|c|}{ Ascorbic acid (mg/ml) } \\
\hline 0.25 & $56.80 \pm 6.17^{\mathrm{a}}$ & $30.75 \pm 10.13^{\mathrm{a}}$ & $84.62 \pm 2.60^{\mathrm{b}}$ & $23.92 \pm 2.30^{\mathrm{ab}}$ & $44.05 \pm 1.62^{\mathrm{b}}$ & $25.93 \pm 3.17^{\mathrm{a}}$ & $53.85 \pm 2.57^{\mathrm{ab}}$ \\
\hline 0.5 & $57.32 \pm 8.65^{\mathrm{a}}$ & $17.75 \pm 4.64^{\mathrm{ab}}$ & $87.35 \pm 135^{\mathrm{ab}}$ & $21.37 \pm 2.70^{\mathrm{b}}$ & $46.20 \pm 2.07^{\mathrm{ab}}$ & $27.33 \pm 0.96^{\mathrm{a}}$ & $51.10 \pm 0.72^{\mathrm{b}}$ \\
\hline 1 & $55.50 \pm 6.07^{\mathrm{a}}$ & $18.40 \pm 5.14^{\mathrm{ab}}$ & $84.40 \pm 0.91^{\mathrm{b}}$ & $23.90 \pm 1.05^{\mathrm{ab}}$ & $44.15 \pm 0.87^{\mathrm{b}}$ & $28.91 \pm 1.12^{\text {aa }}$ & $54.10 \pm 1.39^{\mathrm{ab}}$ \\
\hline 2 & $46.70 \pm 9.05^{\mathrm{a}}$ & $15.85 \pm 6.03^{\mathrm{ab}}$ & $87.55 \pm 2.14^{\mathrm{ab}}$ & $23.71 \pm 0.76^{\mathrm{ab}}$ & $44.37 \pm 0.85^{\mathrm{b}}$ & $28.32 \pm 0.41^{\mathrm{a}}$ & $53.93 \pm 1.00^{\mathrm{ab}}$ \\
\hline 4 & $22.90 \pm 7.53^{b}$ & $8.90 \pm 3.04^{b}$ & $79.81 \pm 5.18^{b}$ & $21.28 \pm 2.45^{\mathrm{b}}$ & $40.57 \pm 2.41^{\mathrm{b}}$ & $26.98 \pm 1.53^{\mathrm{a}}$ & $51.61 \pm 3.19^{\mathrm{ab}}$ \\
\hline
\end{tabular}

abc Values with different superscripts across columns indicate significant differences at $\mathrm{p}<0.05$. PM, progressive motility; VCL, curvilinear speed; VSL, rectilinear speed; VAP, average value; LIN, linearity index; and STR, straightness index. All of the values are expressed as mean \pm SE.

Table II. Effect of adding different concentrations of cysteine and ascorbic acid in HF-20 extender on chilled stallion semen after 90 minutes sperm plasma membrane integrity and morphology in horses. Ten ejaculates were selected from 3 stallions.

\begin{tabular}{lllll}
\hline Treatment & \multicolumn{3}{c}{ Parameters } \\
\cline { 2 - 5 } & HOST (\%) & Normal morphology (\%) & Major abnormalities (\%) & Minor abnormalities (\%) \\
\hline Control (0) & $54.86 \pm 2.45^{\mathrm{a}}$ & $74.30 \pm 5.54^{\mathrm{a}}$ & $1.60 \pm 0.75^{\mathrm{a}}$ & $23.93 \pm 4.78^{\mathrm{a}}$ \\
Cysteine (mg/ml) & & & $2.21 \pm 0.70^{\mathrm{a}}$ & $21.90 \pm 5.94^{\mathrm{a}}$ \\
0.25 & $54.58 \pm 6.46^{\mathrm{a}}$ & $68.48 \pm 4.90^{\mathrm{a}}$ & $1.23 \pm 0.38^{\mathrm{a}}$ & $16.90 \pm 2.46^{\mathrm{a}}$ \\
0.5 & $52.68 \pm 5.77^{\mathrm{a}}$ & $81.76 \pm 2.59^{\mathrm{a}}$ & $1.63 \pm 0.73^{\mathrm{a}}$ & $21.42 \pm 6.16^{\mathrm{a}}$ \\
1 & $48.74 \pm 5.05^{\mathrm{a}}$ & $76.81 \pm 6.91^{\mathrm{a}}$ & $1.70 \pm 0.75^{\mathrm{a}}$ & $22.10 \pm 8.98^{\mathrm{a}}$ \\
2 & $44.52 \pm 6.81^{\mathrm{a}}$ & $76.12 \pm 9.73^{\mathrm{a}}$ & $1.20 \pm 0.45^{\mathrm{a}}$ & $21.75 \pm 7.69^{\mathrm{a}}$ \\
4 & $49.83 \pm 6.61^{\mathrm{a}}$ & $76.90 \pm 8.09^{\mathrm{a}}$ & & $26.98 \pm 2.72^{\mathrm{a}}$ \\
Ascorbic acid (mg/ml) & & & $1.27 \pm 0.88^{\mathrm{a}}$ & $29.03 \pm 5.51^{\mathrm{a}}$ \\
0.25 & $64.82 \pm 3.77^{\mathrm{a}}$ & $68.09 \pm 4.78^{\mathrm{a}}$ & $2.67 \pm 0.96^{\mathrm{a}}$ & $26.75 \pm 5.10^{\mathrm{a}}$ \\
0.5 & $62.88 \pm 7.83^{\mathrm{a}}$ & $68.17 \pm 6.13^{\mathrm{a}}$ & $1.01 \pm 0.60^{\mathrm{a}}$ & $29.17 \pm 5.52^{\mathrm{a}}$ \\
1 & $57.62 \pm 4.65^{\mathrm{a}}$ & $71.30 \pm 5.46^{\mathrm{a}}$ & $1.97 \pm 0.08^{\mathrm{a}}$ & $29.01 \pm 5.54^{\mathrm{a}}$ \\
2 & $59.92 \pm 3.11^{\mathrm{a}}$ & $68.81 \pm 5.53^{\mathrm{a}}$ & $0.05 \pm 0.65^{\mathrm{a}}$ & \\
4 & $55.60 \pm 2.94^{\mathrm{a}}$ & $68.86 \pm 6.08^{\mathrm{a}}$ & & \\
\hline
\end{tabular}

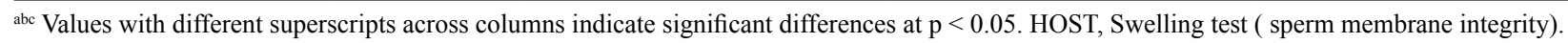

extender supplemented with $0.5 \mathrm{mg} / \mathrm{ml}$ of cysteine had better results $(50 \%)$ compared to $0.5 \mathrm{mg} / \mathrm{ml}$ of ascorbic acid $(10 \%)$. In contrast, using the control, the extender did not present any difference $(40 \%)$ with either cysteine or ascorbic acid as shown in Table V. The association between the control, cysteine, and ascorbic acid groups on the pregnancy rate was depicted using a mosaic presentation. There was no association between the control and cysteine groups in term of pregnancy rate. There was no association between the control and ascorbic acid groups, and an association between the cysteine and ascorbic acid groups on pregnancy rate was observed. 
Table III. Effect of adding different concentrations of cysteine and ascorbic acid in HF-20 extender on post-thawed sperm motility parameters in horses. Ten ejaculates were selected from 3 stallions.

\begin{tabular}{|c|c|c|c|c|c|c|c|}
\hline \multirow[t]{2}{*}{ Treatment } & \multicolumn{7}{|c|}{ Parameters } \\
\hline & Motility (\%) & PM (\%) & VCL $(\mu \mathrm{m} / \mathrm{s})$ & VSL $(\mu \mathrm{m} / \mathbf{s})$ & $\operatorname{VAP}(\mu \mathrm{m} / \mathrm{s})$ & LIN (\%) & STR (\%) \\
\hline Control (0) & $46.92 \pm 10.71^{a}$ & $25.02 \pm 2.85^{\mathrm{a}}$ & $106.66 \pm 3.74^{\mathrm{a}}$ & $32.60 \pm 1.31^{\mathrm{a}}$ & $60.71 \pm 0.53^{\mathrm{a}}$ & $31.98 \pm 1.71^{\mathrm{a}}$ & $54.08 \pm 22.08^{a}$ \\
\hline \multicolumn{8}{|c|}{ Cysteine (mg/ml) } \\
\hline 0.25 & $23.56 \pm 6.67^{\mathrm{b}}$ & $7.41 \pm 3.09^{\mathrm{b}}$ & $74.46 \pm 10.76^{\mathrm{bc}}$ & $21.25 \pm 3.59^{b}$ & $37.93 \pm 5.59^{\mathrm{bc}}$ & $25.10 \pm 3.98^{\mathrm{ab}}$ & $48.16 \pm 7.41^{\mathrm{ab}}$ \\
\hline 0.5 & $35.26 \pm 7.65^{\mathrm{ab}}$ & $8.06 \pm 3.39^{\mathrm{b}}$ & $85.94 \pm 1.84^{\mathrm{ab}}$ & $23.90 \pm 0.78^{\mathrm{ab}}$ & $43.03 \pm 0.86^{b}$ & $28.35 \pm 0.71^{\mathrm{ab}}$ & $54.36 \pm 1.35^{\mathrm{a}}$ \\
\hline 1 & $23.94 \pm 5.49^{b}$ & $5.45 \pm 1.26^{\mathrm{b}}$ & $78.30 \pm 8.02^{\mathrm{ab}}$ & $27.06 \pm 2.73^{\mathrm{ab}}$ & $45.37 \pm 1.76^{b}$ & $31.76 \pm 2.57^{\mathrm{a}}$ & $58.37 \pm 3.58^{\mathrm{a}}$ \\
\hline 2 & $28.75 \pm 4.40^{\mathrm{b}}$ & $7.88 \pm 1.73^{\mathrm{b}}$ & $84.87 \pm 1.64^{\mathrm{ab}}$ & $24.10 \pm 1.85^{\mathrm{ab}}$ & $43.02 \pm 1.48^{b}$ & $29.20 \pm 1.71^{\mathrm{a}}$ & $55.63 \pm 2.68^{\mathrm{a}}$ \\
\hline 4 & $13.14 \pm 4.37^{\mathrm{c}}$ & $4.95 \pm 1.85^{\mathrm{b}}$ & $59.36 \pm 3.74^{\mathrm{b}}$ & $15.61 \pm 4.07^{\mathrm{c}}$ & $29.80 \pm 7.80^{c}$ & $19.70 \pm 5.11^{\mathrm{b}}$ & $37.47 \pm 9.70^{\mathrm{b}}$ \\
\hline \multicolumn{8}{|c|}{ Ascorbic acid (mg/ml) } \\
\hline 0.25 & $20.98 \pm 9.56^{\mathrm{b}}$ & $4.73 \pm 0.74^{\mathrm{b}}$ & $83.00 \pm 2.38^{\mathrm{b}}$ & $20.90 \pm 1.66^{\mathrm{b}}$ & $42.08 \pm 1.72^{b}$ & $26.01 \pm 1.60^{\mathrm{b}}$ & $49.43 \pm 2.39^{\mathrm{ab}}$ \\
\hline 0.5 & $31.00 \pm 6.40^{\mathrm{ab}}$ & $7.00 \pm 3.98^{\mathrm{b}}$ & $84.30 \pm 2.98^{b}$ & $21.41 \pm 1.59^{\mathrm{b}}$ & $43.53 \pm 1.58^{\mathrm{b}}$ & $26.41 \pm 1.57^{\mathrm{b}}$ & $49.19 \pm 2.32^{\mathrm{ab}}$ \\
\hline 1 & $15.83 \pm 6.24^{b}$ & $8.71 \pm 2.54^{\mathrm{b}}$ & $84.31 \pm 1.73^{b}$ & $23.11 \pm 1.34^{b}$ & $44.61 \pm 0.70^{\mathrm{b}}$ & $28.60 \pm 1.66^{\mathrm{ab}}$ & $51.92 \pm 2.24^{\mathrm{ab}}$ \\
\hline 2 & $8.86 \pm 3.00^{c}$ & $4.02 \pm 0.76^{\mathrm{b}}$ & $83.79 \pm 1.79^{b}$ & $21.86 \pm 1.21^{\mathrm{b}}$ & $43.51 \pm 0.99^{b}$ & $27.36 \pm 1.07^{\mathrm{ab}}$ & $50.38 \pm 1.94^{\mathrm{ab}}$ \\
\hline 4 & $5.10 \pm 0.61^{\mathrm{c}}$ & $3.4 \pm 1.06^{\mathrm{b}}$ & $83.6 \pm 2.20^{b}$ & $19.86 \pm 1.17^{\mathrm{b}}$ & $43.03 \pm 0.99^{b}$ & $25.16 \pm 1.44^{\mathrm{b}}$ & $46.56 \pm 1.73^{\mathrm{b}}$ \\
\hline
\end{tabular}

${ }^{a b c}$ Values with different superscripts across columns indicate significant differences at $\mathrm{p}<0.05$. PM, progressive motility.

For abbreviations, see Table I.

Table IV. Effect of different concentrations of cysteine and ascorbic acid in HF-20 extender on post-thawed sperm parameters in horses. Ten ejaculates were selected from 3 stallions.

\begin{tabular}{lllllll}
\hline Treatments & \multicolumn{5}{c}{ Parameters } \\
\cline { 2 - 7 } & HOST \% & Viability \% & $\begin{array}{l}\text { Normal } \\
\text { morphology \% }\end{array}$ & $\begin{array}{l}\text { Major } \\
\text { abnormalities \% }\end{array}$ & $\begin{array}{l}\text { Minor } \\
\text { abnormalities } \\
\text { \% }\end{array}$ & $\begin{array}{l}\text { Acrosome } \\
\text { integrity \% }\end{array}$ \\
\hline Control (0) & $44.49 \pm 10.82^{\mathrm{a}}$ & $32.44 \pm 5.91^{\mathrm{a}}$ & $79.17 \pm 3.88^{\mathrm{ab}}$ & $8.70 \pm 5.71^{\mathrm{a}}$ & $11.57 \pm 1.88^{\mathrm{a}}$ & $76.94 \pm 1.18^{\mathrm{c}}$ \\
Cysteine (mg/ml) & & & & & & \\
0.25 & $18.83 \pm 2.95^{\mathrm{b}}$ & $12.80 \pm 2.59^{\mathrm{b}}$ & $72.41 \pm 6.03^{\mathrm{b}}$ & $4.30 \pm 0.63^{\mathrm{a}}$ & $19.71 \pm 5.26^{\mathrm{a}}$ & $89.34 \pm 1.40^{\mathrm{a}}$ \\
0.5 & $21.74 \pm 2.56^{\mathrm{b}}$ & $20.99 \pm 5.56^{\mathrm{ab}}$ & $82.20 \pm 1.97^{\mathrm{a}}$ & $4.64 \pm 0.43^{\mathrm{a}}$ & $12.91 \pm 2.01^{\mathrm{a}}$ & $88.34 \pm 2.13^{\mathrm{a}}$ \\
1 & $17.55 \pm 1.88^{\mathrm{b}}$ & $18.84 \pm 2.71^{\mathrm{ab}}$ & $84.18 \pm 2.38^{\mathrm{a}}$ & $4.87 \pm 1.18^{\mathrm{a}}$ & $10.81 \pm 2.31^{\mathrm{a}}$ & $87.98 \pm 1.49^{\mathrm{a}}$ \\
2 & $16.31 \pm 2.87^{\mathrm{b}}$ & $21.74 \pm 7.58^{\mathrm{ab}}$ & $80.92 \pm 1.51^{\mathrm{ab}}$ & $7.21 \pm 2.21^{\mathrm{a}}$ & $11.74 \pm 2.06^{\mathrm{a}}$ & $89.36 \pm 0.22^{\mathrm{a}}$ \\
4 & $13.00 \pm 2.97^{\mathrm{b}}$ & $20.20 \pm 7.56^{\mathrm{ab}}$ & $78.61 \pm 2.12^{\mathrm{ab}}$ & $6.08 \pm 1.37^{\mathrm{a}}$ & $15.02 \pm 2.15^{\mathrm{a}}$ & $81.29 \pm 0.13^{\mathrm{b}}$ \\
Ascorbic acid (mg/mI) & & & & & & \\
0.25 & $22.11 \pm 5.44^{\mathrm{b}}$ & $20.25 \pm 4.95^{\mathrm{ab}}$ & $81.43 \pm 3.78^{\mathrm{a}}$ & $7.30 \pm 2.45^{\mathrm{a}}$ & $11.11 \pm 2.35^{\mathrm{a}}$ & $84.65 \pm 1.63^{\mathrm{b}}$ \\
0.5 & $24.14 \pm 6.41^{\mathrm{b}}$ & $27.82 \pm 4.25^{\mathrm{a}}$ & $77.44 \pm 2.69^{\mathrm{a}}$ & $5.95 \pm 2.49^{\mathrm{a}}$ & $16.46 \pm 3.02^{\mathrm{a}}$ & $84.19 \pm 1.93^{\mathrm{b}}$ \\
1 & $24.73 \pm 4.16^{\mathrm{b}}$ & $25.50 \pm 2.72^{\mathrm{a}}$ & $84.11 \pm 1.79^{\mathrm{a}}$ & $5.36 \pm 2.08^{\mathrm{a}}$ & $10.40 \pm 1.20^{\mathrm{a}}$ & $94.21 \pm 1.59^{\mathrm{a}}$ \\
2 & $12.96 \pm 2.03^{\mathrm{b}}$ & $17.83 \pm 7.58^{\mathrm{ab}}$ & $82.76 \pm 1.67^{\mathrm{a}}$ & $4.14 \pm 1.35^{\mathrm{a}}$ & $13.32 \pm 1.43^{\mathrm{a}}$ & $91.00 \pm 1.00^{\mathrm{a}}$ \\
4 & $20.65 \pm 3.68^{\mathrm{b}}$ & $5.56 \pm 0.72^{\mathrm{b}}$ & $78.72 \pm 3.71^{\mathrm{a}}$ & $6.42 \pm 2.59^{\mathrm{a}}$ & $14.70 \pm 2.98^{\mathrm{a}}$ & $72.80 \pm 0.14^{\mathrm{c}}$ \\
\hline
\end{tabular}

${ }^{\text {abc }}$ Values with different superscripts across columns indicate significant differences at $\mathrm{p}<0.05$. HOST, swelling test (sperm membrane integrity). All of the values are expressed as mean $\pm \mathrm{SE}$.

\section{DISCUSSION}

Antioxidants such as cysteine and ascorbic acid were added into a freezing extender that was used for semen cryopreservation and oocyte and embryo preservation (Allai et al., 2018; Varghese et al., 2009). However, the imbalance between the reactive oxygen species (ROS) and the antioxidant or the inability of the antioxidant to 
counteract the ROS during semen cryopreservation will damage the sperm due to oxidative stress that occurs during semen cryopreservation (Agarwal et al., 2008; de Lamirande and O'Flaherty, 2008). The lipid peroxidation of horse sperm increases during semen preservation procedures, especially in the sperm midpiece (Neild et al., 2005). The present study investigated the effects of adding different concentrations of cysteine or ascorbic acid to HF-20 extender to evaluate the oxidative stress level and frozen semen quality in horses.

Table V. The pregnancy rate of HF-20 extender supplemented with $0.5 \mathrm{mg} / \mathrm{ml}$ cysteine and $0.5 \mathrm{mg}$ / $\mathrm{ml}$ ascorbic acid. Thirty mares were selected for the artificial insemination.

\begin{tabular}{llll}
\hline Extenders & $\begin{array}{l}\text { Inseminat- Conceived } \\
\text { ed mares }\end{array}$ & $\begin{array}{l}\text { Pregnancy } \\
\text { mares }\end{array}$ & rate (\%) \\
\hline Control (0) & 10 & 4 & $40.0^{\mathrm{ab}}$ \\
$0.5 \mathrm{mg} / \mathrm{ml}$ cysteine & 10 & 5 & $50.0^{\mathrm{a}}$ \\
$0.5 \mathrm{mg} / \mathrm{ml}$ ascorbic acid & 10 & 1 & $10.0^{\mathrm{b}}$ \\
\hline
\end{tabular}

abc Values with diverse superscripts within columns represent significant variations at $\mathrm{p}<0.05$.

There was no effect of adding cysteine on the spermatozoa motility pattern, sperm membrane integrity and morphology in all concentrations added, after cooling for 90 minutes. The cysteine supplementation maintained the spermatozoa cytological characteristics for 90 minutes in the cooling chamber. In view of this, adding cysteine could enhance the chilled semen quality, and in turn protect the sperm from the oxidative stress, as reported by (De Oliveira et al., 2015).

In the present study, the deleterious effects of adding ascorbic acid to the frozen semen extender were observed in the high ascorbic acid concentrations, after cooling for 90 minutes, on the spermatozoa motility pattern. The adverse effects of ascorbic acid might be due to the rise of oxidative stress on the treated groups, which increase the lipid peroxidation on the sperm membrane. A study by Gibb et al. (2014) demonstrated a high correlation between semen quality and oxidative stress. The freezing capacity of the groups treated with ascorbic acid could be reduced due to the low sperm membrane fluidity and the disruption of the sperm membrane as suggested by Ball (2008).

In the present study, the oxidative stress in the semen cryopreserved with cysteine had low levels of oxidative stress (LOS) in all of the concentrations. Although this level of oxidative stress consider unable to damage the sperm, it was higher compared to the control group. The current result elucidate the inability of cysteine to protect the frozen semen during freezing procedures. This finding is in agreement with previous studies (Çoyan et al., 2011) that reported no effect was observed when adding cysteine to prevent lipid peroxidation in the cryopreserved semen of rams.

On the other hand, instead of decreasing the oxidative stress in the cryopreserved horse semen, Oxisperm tests revealed higher oxidative stress in groups treated with ascorbic acid. High concentrations of ascorbic acid (between $2 \mathrm{mg} / \mathrm{ml}$ and $4 \mathrm{mg} / \mathrm{ml}$ ) led to high oxidative stress that caused pathological effects on sperm function and structure. Although the groups treated with 0.25 , 0.5 , and $1 \mathrm{mg} / \mathrm{ml}$ of ascorbic acid had greater oxidative stress compared to the control group, the levels of ROS consider unable to damage the sperms. The addition of ascorbic acid reveals to increase the oxidative stress and effect on the spermatozoa cryosurvival during cryopreservation. This is inconsistent with past findings. For instance, studies using bovines (Hu et al., 2010) and goats (Memon et al., 2012) semen found that freezing extenders that were added to ascorbic acid protected the post-thawed semen from oxidative stress. But a study using dogs (Michael et al., 2008) reported a negative influence on canine sperm quality parameters after adding different concentrations of ascorbic acid. However, high oxidative stress by adding ascorbic acid to the freezing extenders did not correspond to the results obtained from the study of (Franco et al., 2013). The varying effects of the antioxidant supplementation between the species might be due to the different compositions of spermatozoa among these species. In a study conducted by (Gibb et al., 2014) in a horse, reported high production of ROS in stallion spermatozoa compared to other species. Stallion sperm depends on oxidative phosphorylation (OXPHOS) to produce ATP, which makes stallion spermatozoa to produce more ROS than other species. Furthermore, the particular composition of the polyunsaturated lipids of stallion spermatozoa makes them more sensitive to lipid peroxidation (Varner et al., 2015).

The results of adding the antioxidants to the frozen semen extenders in the stallions have been contradicting. Many studies reported better-frozen semen quality with better protection against oxidative stresses during freezing procedures with antioxidant supplementation in the stallion. Adding glutathione (De Oliveira et al., 2013), butylatedhydroxyanisole (Seifi-Jamadi et al., 2016) and MnTBAP ameliorate (Shojaeian et al., 2018) enhanced the post-thawed semen quality. In contrast, some studies reported no protective effects of the antioxidants during semen cryopreservation. It was concluded that no benefits were brought about from the addition of alpha lipoic acid to frozen semen (Hussain et al., 2011). The antioxidant 
performance to encounter the excessive ROS effects is highly correlated with the antioxidant type and its concentrations.

We hypothesized that the acidification of the postthawed semen with cysteine or ascorbic acid during the freezing procedure increased the oxidative stress in the samples. A prior study (Liu et al., 2016) noted a $\mathrm{pH}$ decline during long-term storage. Furthermore, $\mathrm{pH}$ highly affects ROS as suggested in a previous study (Clement et al., 2011). Cysteine and ascorbic acid play dual roles in ROS. Despite their ability to scavenge reactive oxygen species, they can be harmful to spermatozoa. Cysteine can conjugate with electrophiles, which might increase the oxidative stress in semen samples due to the thiol side of cysteine (MartinMuñoz et al., 2015). Moreover, ascorbic acid can exhibit oxidizing activity in the presence of transition metals (Barbosa et al., 2012). In agreement with our findings Michael et al. (2008) reported an increase in free radical production in cryopreserved semen that were treated with ascorbic acid. These results could be due to the change in the $\mathrm{pH}$ in the post-thawed semen treated with ascorbic acid.

Post-thawed semen supplemented with cysteine or ascorbic acid had a negative effect on sperm motility and sperm membrane integrity and viability compared to controls. This study differs from that of Sariözkan et al. (2009) who reported that the addition of cysteine exhibited significant protection on post-thawed bull semen motility, viability, and membrane integrity. This is similar to the studies conducted on rams (Uysal and Bucak, 2007) and goats (Memon et al., 2012). The current results emphasize previous findings (Jẹdrzejczak et al., 2005; Ko et al., 2014; Saleh and Agarwal, 2002) that reported a high correlation between reactive oxygen species (ROS) and sperm motility, sperm membrane integrity and viability. This effect may be due to the lipid peroxidation of the sperm membrane that diminished axonemal protein phosphorylation. Although the low concentration of cysteine and ascorbic acid showed better motion parameters than those with higher concentration, the control group had the best sperm motility and membrane integrity and viability. This means that the sperm in the control group was protected from oxidative stress. This result emphasizes previous findings (Filho et al., 2009). The authors postulated that frozen semen extenders had sufficient antioxidants that are able to counteract ROS during semen cryopreservation.

The sperm motility patterns (VSL, VCL, VAP, STR, and LIN) are best indicators of sperm capacity and hyperactivity that predict the spermatozoa's ability to penetrate the oocytes' zona pellucida (McPartlin et al., 2009). However, high spermatozoa velocity is associated with the total percentage of sperm's progressive motility to consider as a critical criterion (Vidament et al., 2012). The addition of cysteine and ascorbic acid in the present results had a deleterious effect on sperm velocity. These results correspond well to a previous study that reported a high correlation between the level of oxidative stress and sperm motility (Kao et al., 2008). This could be due to the ability of the control extender to control the $\mathrm{pH}$ and protect the sperm from oxidative stress during semen preservation.

However, the addition of antioxidant cysteine or ascorbic acid in the current study showed a high capacity to protect acrosome integrity during cryopreservation when compared to the control, except at a cysteine concentration of $4 \mathrm{mg} / \mathrm{ml}$ and an ascorbic acid concentration of $4 \mathrm{mg} / \mathrm{ml}$. Although the sperm morphology in these concentrations provided better results than the control group, the improvement was not significant. The same result was observed by Ceylan and Serin (2007) that used cooled dog semen. These results also conformed to the findings of Saleh and Agarwal (2002) that reported low concentrations of antioxidants in spermatozoa cytoplasm and the inability of intracellular antioxidants to protect the plasma membrane. These findings led to the hypothesis that cysteine and ascorbic acid may play a role in enhancing intracellular antioxidants due to their ability to penetrate the sperm membrane. Furthermore, the activation of calcium channels leading to an increase in intracellular $\mathrm{Ca}^{++}$ may be responsible for the capacitation of spermatozoa. Normal sperm morphology and the acrosome structure are insufficient to indicate spermatozoa's acrosome function (Varner, 2008).

Therefore, the number of conceived mares is the main indicator of the quality of frozen semen. Supplementing HF-20 extender with $0.5 \mathrm{mg} / \mathrm{ml}$ of cysteine revealed a better pregnancy rate than using $0.5 \mathrm{mg} / \mathrm{ml}$ of ascorbic acid. No significant differences were observed in the control group. The pregnancy rate in the control and cysteine extender groups was $40 \%$ and $50 \%$, respectively, which is within the range of previous findings (Samper et al., 2008; Waheed and Pratap, 2016). The sperm motility revealed higher sensitivity to the OS than other parameters such as acrosome integrity, viability and sperm membrane integrity. Thus, low motility could be observed without any decrease in the other parameters in the high levels of OS as described by Ball (2008). Using $0.5 \mathrm{mg} /$ $\mathrm{mL}$ cysteine in the frozen extenders in the present study which revealed adequate pregnancy rates in comparison with previous research works that suggested that it can be used commercially as elucidated by Clulow et al. (2008). Cysteine might play a role in sperm acrosome reaction and hyperactivity that might enhance the ability of the spermatozoa to penetrate and fertilize the oocyte. The overall percentage of mares, which conceived using cysteine might increase if a higher number of mares were 
used. The poor quality of the ascorbic acid extender could be due to the reduction in the acrosome reaction and thus the inability of the sperm to penetrate the zona pellucida of oocytes. In addition to that, the excessive $\mathrm{Ca}^{2+}$ concentration in the samples supplemented with ascorbic acid may have increased the premature acrosome reaction in the frozen semen, which effected the spermatozoa fertility. The premature acrosome reaction could be as a result of the disruption of the calcium channel, which occurred due to the protein oxidation on the sperm membrane. This finding is in harmony with the work of Witte and Schäfer-Somi (2007).

Antioxidant activity appears to be affected by any change in the spermatozoa composition and the semen environment such as temperature and $\mathrm{pH}$ levels. Tavilani et al. (2008) noted an increase in the lipid peroxidation in the seminal plasma for asthenozoospermia samples despite the fact that enzymatic antioxidant concentrations were high. In the normozoospermic sample, the antioxidants showed good protection effects, aiding the spermatozoa with lipid peroxidation. Furthermore, the levels of reactive oxygen species ROS in the testicular tumor cases was higher than normal with the same readings of antioxidants as observed in men (Sposito et al., 2017). This may be due to the high levels of free radicals associated with these cases or the change in the pH levels. Härtlová et al. (2013) detected a change in the semen $\mathrm{pH}$ towards acidity in the stallion's semen when subjected to stress. The change in the semen acidity was as result of an increase in lipid peroxidation in the stressed stallion. The antioxidants type and associated concentration that is supplemented to the semen extender should be under the appropriate environment to get better antioxidant protection for the spermatozoa from oxidative stresses. Moreover, each antioxidant has a preferred environment, which allows it to achieve its highest activity. The deleterious effects of adding cysteine and ascorbic acid in this current study can be traced back to the change in the extended semen $\mathrm{pH}$ through the freezing and thawing processes.

\section{CONCLUSION}

In conclusion, the findings of the current study demonstrated that HF-20 extender adequately protects spermatozoa from oxidative stress. Although the addition of cysteine and ascorbic acid improved the morphology and acrosome integrity, these antioxidants increased the oxidative stress on the post-thawed horse semen and had an adverse effect on other semen parameters. Cysteine supplementation did not have a positive effect on the frozen semen fertility parameters or pregnancy rate. In the current results, ascorbic acid reduced the overall fertility of frozen semen. Cysteine and ascorbic acid did not seem to be an efficient antioxidant to counteract the oxidative stress during cryopreservation of stallion semen. Therefore, the supplementation of these antioxidants to the HF-20 extender needs further modifications in order to improve its protective ability due to changes in $\mathrm{pH}$ during semen cryopreservation procedures.

\section{ACKNOWLEDGMENTS}

We would like to appreciate Prof. Dr. Ibrahim Al Homidan who is the Head of the Animal Production and Breeding department in Qassim University's Veterinary Medicine and Agriculture faculty. Also, we would like to thank all staff members working in the university farm's Horse Research Unit for the assistance and cooperation they accorded us. We would like to especially thank Dr. Abdul Ganiy Alfadhl who is the King Abdulaziz Arabian Horses Center Director General and all staff members for giving permission to use their stallions and facilities in these experiments.

\section{Statement of conflict of interest}

The authors have declared no conflict of interest.

\section{REFERENCES}

Agarwal, A., 2003. Significance of oxidative stress and sperm chromatin damage in male infertility. In: Male Fertility and Lipid Metabolism (eds. S. De Vriese and A. Christophe). AOCS Press, Champaign, IL. US. pp. 157-183. https://doi. org/10.1201/9781439822234.ch13

Agarwal, A., Makker. K. and Sharma, R., 2008. Clinical relevance of oxidative stress in male factor infertility: An update. Am. J. Reprod. Immunol., 59: 2-11. https://doi.org/10.1111/j.16000897.2007.00559.x

Agarwal, A., Nallella, K.P., Allamaneni, S.S.R. and Said, T.M., 2004. Role of antioxidants in treatment of male infertility: An overview of the literature. Reprod. Biomed. Online, 8: 616-627. https://doi. org/10.1016/S1472-6483(10)61641-0

Agarwal, A., Prabakaran, S. and Allamaneni, S., 2006. What an andrologist/urologist should know about free radicals and why. Urology, 67: 2-8. https://doi. org/10.1016/j.urology.2005.07.012

Agarwal, A., Virk, G., Ong, C. and Plessis, S., 2014. Effect of oxidative stress on male reproduction. World J. Mens Hlth., 32: 1. https://doi.org/10.5534/ wjmh.2014.32.1.1

Aitken, R.J., 2017. Reactive oxygen species as mediators 
of sperm capacitation and pathological damage. Mol. Reprod. Dev., 84: 1039-1052. https://doi. org $/ 10.1002 / \mathrm{mrd} .22871$

Allai, L., Benmoula, A., Marciane da Silva M. and Nasser, B., 2018. Supplementation of ram semen extender to improve seminal quality and fertility rate. Anim. Reprod. Sci., 192: 6-17. https://doi. org/10.1016/j.anireprosci.2018.03.019

Aurich, J.E., 2012. Artificial insemination in horsesmore than a century of practice and research. J. Equine Vet. Sci., 32: 458-463. https://doi. org/10.1016/j.jevs.2012.06.011

Ball, B.A., 2008. Oxidative stress, osmotic stress and apoptosis: Impacts on sperm function and preservation in the horse. Anim. Reprod. Sci., 107: 257-267. https://doi.org/10.1016/j. anireprosci.2008.04.014

Barbosa, N.B.V., Lissner, L.A., Klimaczewski, C.V., Colpo, E. and Rocha, J.B.T., 2012. Ascorbic acid oxidation of thiol groups from dithiotreitol is mediated by its conversion to dehydroascorbic acid. EXCLI J., 11: 604-612.

Bui, A.D., Sharma, R., Henkel, R. and Agarwal, A., 2018. Reactive oxygen species impact on sperm DNA and its role in male infertility. Andrologia, 50: 1-10. https://doi.org/10.1111/and.13012

Ceylan, A. and Serin, I., 2007. Influence of ascorbic acid addition to the extender on dog sperm motility, viability and acrosomal integrity during cooled storage. Rev. Med. Vet. (Toulouse), 158: 384-387.

Clement, M.V., Akram, S., Kumar, A.P., Chang, M.K.X. and Pervaiz, S., 2011. 3. Reactive oxygen species, intracellular $\mathrm{pH}$, and cell fate: A link between chronic inflammation and cancer. 2011 Available at http://www.biology-pages.info/R/ROS.html.

Clulow, J.R., Buss, H., Sieme, H., Rodger, J.A., Cawdell-Smith, A.J., Evans,G., Rath, D., Morris, L.H.A. and Maxwell, W.M.C., 2008. Field fertility of sex-sorted and non-sorted frozen-thawed stallion spermatozoa. Anim. Reprod. Sci., 108: 287-297. https://doi.org/10.1016/j.anireprosci.2007.08.015

Çoyan, K., Başpinar, N., Bucak, M.N. and Akalin, P.P., 2011. Effects of cysteine and ergothioneine on post-thawed Merino ram sperm and biochemical parameters. Cryobiology, 63: 1-6. https://doi. org/10.1016/j.cryobiol.2011.04.001

De Lamirande, E. and O'Flaherty, C., 2008. Sperm activation: Role of reactive oxygen species and kinases. Biochim. biophys. Acta - Proteins Proteomics, 1784: 106-115. https://doi. org/10.1016/j.bbapap.2007.08.024

De Oliveira, R.A., De Oliveira Viu, M.A. and
Gambarini, M.L., 2015. Cooling of equine semen at $16^{\circ} \mathrm{C}$ for 36 hoursh with addition of different glutathione concentrations. Semin Agrar., 36: 3699-3704. 0359.2015v36n6p3699

De Oliveira, R.A., Wolf, C.A., De Oliveira Viu, M.A.Ô. and Gambarini, M.L., 2013. Addition of glutathione to an extender for frozen equine semen. $J$. Equine Vet. Sci., 33: 1148-1152. https://doi.org/10.1016/j. jevs.2013.05.001

De Pinto, V., Reina, S., Gupta, A., Mession, A. and Mahalashmi, R., 2016. Role of cysteines in mammalian VDAC isoforms' function. Biochim. biophys. Acta - Bioenerg., 1857: 1219-1227. https://doi.org/10.1016/j.bbabio.2016.02.020

Donnelly, E.T., McClure, N. and Lewis, S.E., 1999. Antioxidant supplementation in vitro does not improve human sperm motility. Fertil. Steril., 72: 484-495. https://doi.org/10.1016/S00150282(99)00267-8

Du, J., Cullen, J.J. and Buettner, G.R., 2012. Ascorbic acid: Chemistry, biology and the treatment of cancer. Biochim. biophys. Acta - Rev. Cancer, 1826: 443457. https://doi.org/10.1016/j.bbcan.2012.06.003

Filho, I.C.B., Pederzolli, C.D., Sgaravatti, A.M., Gregory R.M., Filho, C.S.D., Jobim, M.I.M. and Mattos, R.C., 2009. Skim milk-egg yolk based semen extender compensates for non-enzymatic antioxidant activity loss during equine semen cryopreservation. Anim. Reprod., 6: 392-399.

Franco, J.S.V., Chaveiro, A., Góis, A., and Da Silva, F.M., 2013. Effects of $\alpha$-tocopherol and ascorbic acid on equine semen quality after cryopreservation. J. Equine Vet. Sci., 33: 787-793. https://doi. org/10.1016/j.jevs.2012.12.012

Gibb, Z., Lambourne, S.R. and Aitken, R.J., 2014. The paradoxical relationship between stallion fertility and oxidative stress1. Biol. Reprod., 91: 1-10. https://doi.org/10.1095/biolreprod.114.118539

Härtlová, H., Rajmon, R., Krontorádová, I., Mamica, J., Zita, L., Klabanova, P. and Ceenocky, A., 2013. Semen quality, lipid peroxidation and seminal plasma antioxidant status in horses with different intensities of physical exercise. Acta Vet. Brno., 82: 31-35. https://doi.org/10.2754/avb201382010031

Hu, J.H., Tian, W.Q., Zhao, X.L., Zan, L.S., Wang, H., Li, Q. and Xin, Y., 2010. The cryoprotective effects of ascorbic acid supplementation on bovine semen quality. Anim. Reprod. Sci., 121:72-77. https://doi. org/10.1016/j.anireprosci.2010.04.180

Hussain, J., Salam, A. and Gohar, A., 2011. A study on the cryopreservation of stallion semen with alpha 
lipoic acid. J. Pharm., 01: 21-26.

Jẹdrzejczak, P., Frạczek, M., Szumałakạkol, A., Taszarek-Hauke, G., Pawelczyk, L. and Kurpisz, M., 2005. Consequences of semen inflammation and lipid peroxidation on fertilization capacity of spermatozoa in in vitro conditions. Int. J. Androl., 28: 275-283. https://doi.org/10.1111/j.13652605.2005.00547.x

Kao, S.H., Chao, H.T., Chen, H.W., Hwang, T.I., Liga, T.L. and Wei, Y.H., 2008. Increase of oxidative stress in human sperm with lower motility. Fertil. Steril., 89: 1183-1190. https://doi.org/10.1016/j. fertnstert.2007.05.029

Ko, E.Y., Sabanegh, E.S. and Agarwal, A., 2014. Male infertility testing: Reactive oxygen species and antioxidant capacity. Fertil. Steril., 102: 1518-1527. https://doi.org/10.1016/j.fertnstert.2014.10.020

Liu, C.H., Dong, H.B., Ma, D.L., Li Y.W., Han, D., Luo, M.J., Chang, Z.L. and Tan J.H., 2016. Effects of $\mathrm{pH}$ during liquid storage of goat semen on sperm viability and fertilizing potential. Anim. Reprod. Sci., 164: 47-56. https://doi.org/10.1016/j. anireprosci.2015.11.011

Loomis, P.R., and Graham, J.K., 2008. Commercial semen freezing: Individual male variation in cryosurvival and the response of stallion sperm to customized freezing protocols. Anim. Reprod. Sci., 105: 119-128. https://doi.org/10.1016/j. anireprosci.2007.11.010

MartinMuñoz, P., Ferrusola, C.O., Vizuete, G., Davila, M.P., Martinez, H.R. and Pena, F.J., 2015. Depletion of intracellular thiols and increased production of 4-hydroxynonenal that occur during cryopreservation of stallion spermatozoa lead to caspase activation, loss of motility, and cell death. Biol. Reprod., 93: 1-11. https://doi.org/10.1095/ biolreprod.115.132878

McPartlin, L.A., Suarez, S.S., Czaya, C.A., Hinrichs, K. and Bedford-Guaus, S.J., 2009. Hyperactivation of stallion sperm is required for successful in vitro fertilization of equine oocytes. Biol. Reprod., 81: 199-206. https://doi.org/10.1095/ biolreprod.108.074880

Memon, A.A., Wahid, H., Rosnina, Y., Goh, Y.M., Ebrahimi, M. and Nadia, F.M., 2012. Effect of antioxidants on post thaw microscopic, oxidative stress parameter and fertility of Boer goat spermatozoa in tris egg yolk glycerol extender. Anim. Reprod. Sci., 136: 55-60. https://doi. org/10.1016/j.anireprosci.2012.10.020

Michael, A.J., Alexopoulos, C., Pontiki, E.A., Hadjipavlou-Litina, Saratsis, P.H., Ververidis,
H.N. and Boscos, C.M., 2008. Quality and reactive oxygen species of extended canine semen after vitamin $\mathrm{C}$ supplementation. Theriogenology, 70: $\quad 827-835$. https://doi.org/10.1016/j. theriogenology.2008.05.043

Morielli, T. and O'Flaherty, C., 2015. Oxidative stress impairs function and increases redox protein modifications in human spermatozoa. Reproduction, 149: 113-123. https://doi.org/10.1530/REP-140240

Murcia-Robayo, R.Y., Jouanisson, E., Beauchamp, G. and Diaw, M., 2018. Effects of staining method and clinician experience on the evaluation of stallion sperm morphology. Anim. Reprod. Sci., 188: 165-169. https://doi.org/10.1016/j. anireprosci.2017.11.021

Neild, D., Chaves, G., Flores, M., Mora, N., Beconi, M. and Aguero, A., 1999. Hypoosmotic test in equine spermatozoa. Theriogenology, 51: 721-727. https://doi.org/10.1016/S0093-691X(99)00021-7

Neild, D.M., Brouwers. J.F.H.M., Colenbrander, B., Aguero, A. and Gadelia, B.M., 2005. Lipid peroxide formation in relation to membrane stability of fresh and frozen thawed stallion spermatozoa. Mol. Reprod.Dev., 72: 230-238. https://doi.org/10.1002/ mrd.20322

Nishikawa, Y., 1975. Studies on the preservation of raw and frozen horse semen. J. Reprod. Fertil. Suppl., pp. 99-104.

Saleh, R.A. and Agarwal, A., 2002. Oxidative stress and male infertility: From research bench to clinical practice. J. Androl., 23: 737-752.

Samper, J.C., 2009. Uterine edema in the mare. Equine Breed Manage. Artif. Insemin., pp. 133-138. https:// doi.org/10.1016/B978-1-4160-5234-0.00012-X

Samper, J.C., Gomez, I. and Sanchez, R., 2008. Rectally guided or hysteroscopic insemination: Is there a difference? J. Equine Vet. Sci., 28: 640-644. https:// doi.org/10.1016/j.jevs.2008.10.014

Sariözkan, S., Bucak, M.N., Tuncer, P.B., Ulutas, P.A. and Bilgen, A., 2009. The influence of cysteine and taurine on microscopic-oxidative stress parameters and fertilizing ability of bull semen following cryopreservation. Cryobiology, 58: 134-138. https://doi.org/10.1016/j.cryobiol.2008.11.006

Seifi-Jamadi, A., Kohram, H., Zareh-Shahne, A., Dehghanizadeh, P. and Ahmad, E., 2016. Effect of various concentrations of butylated hydroxyanisole and butylated hydroxytoluene on freezing capacity of Turkman stallion sperm. Anim. Reprod. Sci., 170: 108-113. https://doi.org/10.1016/j. anireprosci.2016.04.010 
Shojaeian, K., Nouri, H. and Kohram, H., 2018. Does MnTBAP ameliorate DNA fragmentation and in vivo fertility of frozen-thawed Arabian stallion sperm? Theriogenology, 108: 16-21. https://doi. org/10.1016/j.theriogenology.2017.11.019

Smits, R.M., Mackenzie-Proctor, R., Fleischer, K., and Showell, M.G., 2018. Antioxidants in fertility: impact on male and female reproductive outcomes. Fertil. Steril., 110: 578-580. https://doi. org/10.1016/j.fertnstert.2018.05.028

Sobhani, A., Eftekhaari, T.E., Shahrzad, M.E., Natami, M. and Fallahi, S., 2015. Antioxidant effects of brown algae sargassum on sperm parameters: CONSORT-compliant article. Medicine, 94: e1938. https://doi.org/10.1097/MD.0000000000001938

Sposito, C., Camargo, M., Tibaldi, D.S., Barradas, V., Cedenho, A.P., Nichi, M., Bertolla, R.P. and Spaine, D.M., 2017. Antioxidant enzyme profile and lipid peroxidation products in semen samples of testicular germ cell tumor patients submitted to orchiectomy. Int. Braz.J. Urol., 43: 644-651.https:// doi.org/10.1590/s1677-5538.ibju.2016.0323

Tavilani, H., Goodarzi, M.T., Vaisi-Raygani, A., Salimi, S. and Hassanzadeh, T., 2008. Activity of antioxidant enzymes in seminal plasma and their relationship with lipid peroxidation of spermatozoa. Int. Braz. J. Urol., 34: 485-491. https://doi.org/10.1590/ S1677-55382008000400011

Treulen, F., Elena, M., Aguila, L., Uribe, P. and Felmer, R., 2018. Cryopreservation induces mitochondrial permeability transition in a bovine sperm model. Cryobiology, 83: 65-74. https://doi.org/10.1016/j. cryobiol.2018.06.001

Uysal, O. and Bucak, M.N., 2007. Effects of oxidized glutathione, bovine serum albumin, cysteine and lycopene on the quality of frozen-thawed ram semen. Acta Vet. Brno, 76: 383-390. https://doi. org/10.2754/avb200776030383

Varghese, A.C., Nagy, Z.P. and Agarwal, A., 2009. Current trends, biological foundations and future prospects of oocyte and embryo cryopreservation. Reprod. Biomed. Online, 19: 126-140. https://doi. org/10.1016/S1472-6483(10)60056-9

Varner, D.D., 2008. Developments in stallion semen evaluation. Theriogenology, 70: 448-462. https:// doi.org/10.1016/j.theriogenology.2008.04.023

Varner, D.D., Gibb, Z. and Aitken, R.J., 2015. Stallion fertility: A focus on the spermatozoon. Equine Vet. J., 47: 16-24. https://doi.org/10.1111/evj.12308

Vidament, M., Magistrini, M., Le Foll, Y., Levillain, N., Yvon, J.M., Duchamp, G. and Blesbois, E., 2012. Temperatures from 4 to $15^{\circ} \mathrm{C}$ are suitable for preserving the fertilizing capacity of stallion semen stored for $22 \mathrm{~h}$ or more in INRA96 extender. Theriogenology, 78: 297-307. https://doi. org/10.1016/j.theriogenology.2012.01.018

Waheed, M.M. and Pratap, N., 2016. Effect of extenders and insemination protocol on the fertilizing capacity of cryopreserved arabian horse semen. SOJ Vet. Sci., 2: 1-8. https://doi.org/10.15226/23812907/2/2/00117

Witte, T.S. and Schäfer-Somi, S., 2007. Involvement of cholesterol, calcium and progesterone in the induction of capacitation and acrosome reaction of mammalian spermatozoa. Anim. Reprod. Sci., 102: 181-193. https://doi.org/10.1016/j. anireprosci.2007.07.007

Zhang, W., Yi, K., Chen, C., Hou, X. and Zhou, X., 2012. Application of antioxidants and centrifugation for cryopreservation of boar spermatozoa. Anim. Reprod. Sci., 132: 123-128. https://doi. org/10.1016/j.anireprosci.2012.05.009 